\title{
Engajamento e ação Política: Leonardo Boff na blogosfera
}

\author{
Engagement and Political action: Leonardo Boff blogosphere
}

\section{Christiane Jalles de Paula}

Doutora em Ciências Sociais Professora da Universidade Federal de Juiz de Fora christianejalles@gmail.com

Resumo: Este texto reflete sobre aspectos da atuação do intelectual Leonardo Boff na praça pública, analisando os artigos que publicou entre 2011 e 2016 em seu blog www.leonardoboff.wordpress.com. O trabalho buscou entender as pautas, agendas e interlocuções nas quais Leonardo Boff engajou-se. Fazendo uso das categorias de Norberto Bobbio de intelectual: ideólogo/experto, percebe-se que Leonardo Boff ora apela para um, ora para o outro papel de intelectual. Em ambos, Boff afirma um engajamento e ação política marcada pelas pautas progressistas do século XXI.

Palavras-chave: Intelectual, Política-Brasil Século XXI, Religião, Leonardo Boff.

\begin{abstract}
This text reflects on aspects of the performance of the intellectual Leonardo Boff in the public square, analyzing the articles that published between 2011 and 2016 in his blog www.leonardoboff.wordpress.com. The work sought to understand the guidelines, agendas and dialogues that Leonardo Boff engaged. Making use of the categories of Norberto Bobbio as an intellectual: ideologist / expert, one can see that Leonardo Boff now appeals to one, sometimes to another intellectual role. In both, Boff affirms an engagement and political action marked by the progressive guidelines of the 21 st century.
\end{abstract}

Keywords: Intellectual, 21st century PoliticsBrazil, Religion, Leonardo Boff. 


\section{Introdução}

O papel e a função dos intelectuais nas sociedades são temas caros às Ciências Sociais. Vários pensadores balizaram tal debate como: Antonio Gramsci, Jean-Paul Sartre, Michel Lowy, Jean-François Sirinelli, entre outros (WINOCK, 2000). Karl Mannheim, em Ideologia e Utopia (1986), trabalhou com a relação existênciaconhecimento. Para este autor, não é possível desvincular o conhecimento das bases sociais e históricas de sua própria produção, bem como é impossível que seus produtores (os intelectuais) os produzam apartados de condicionantes sociais - ainda que eles (os intelectuais) assim se refiram aos seus trabalhos. Há, aqui, ênfase aos aspectos relacionais e perspectivistas uma vez que, para Mannheim, as ideias têm origem social e histórica, e cabe à sociologia do conhecimento trazer à tona as imbricações ideias/produtores a partir do lugar/posição social daqueles que produzem e reverberam tais posicionamentos (MANNHEIM, 1986). É sob esta embocadura que este texto examina a atuação de Leonardo Boff entre 2011 e 2016 em seu blog (www.leonardoboff.wordpress.com).

Considerado um dos grandes teólogos mundiais, e fundamental na teologia latino-americana, a trajetória e os escritos de Leonardo Boff veem sendo estudados por vários autores que ressaltam sua contribuição para a constituição novas formas de entender o cristianismo (SILVA, 2012; COSTA, 2016). Sem dúvida, a atuação e a reflexão de Leonardo Boff nos campos teológicos e sociais da Igreja Católica são muito importantes. Mas, neste texto, trataremos da atuação de Leonardo Boff extramuros do catolicismo e que recebe pouca atenção dos pesquisadores. É claro que sua atuação no Urbi et Orbi constituí um todo. Todavia, a análise aqui é a sua atuação na cena pública laica que ganha força quando Leonardo Boff renuncia à Ordem dos Franciscanos, como veremos abaixo, e adere à forma de comunicação mediada pelo computador, com a criação de site pessoal, endereço no Twitter, fanpage no Facebook e blog. Leonardo Boff é, portanto, um intelectual aberto às novas formas de comunicação, e será por meio desses meios de comunicação que exercerá sua missão. E, conforme nos ensinou Mannheim, para compreender a missão do intelectual - quais são as ideias e como é o exercício de práxis intelectual - precisamos ter claro quais são a origem e as relações históricas-sociais que forjam a perspectiva da ação intelectual. No caso em tela, não 
devemos perder de vista os condicionantes históricos e sociais que sustentam as posições do intelectual Leonardo Boff.

Antes de prosseguir, cumpre umas palavras sobre a metodologia e as fontes que usamos. Em relação às últimas, foram objetos da análise tanto os escritos de Leonardo Boff no blog em tela, como os comentários de usuários/frequentadores do blog e as respostas oferecidas por Boff a eles. Sobre a metodologia, optamos pelo método qualitativo: a etnografia virtual, também chamada nos estudos de Mídia de Netnografia.

A Netnografia é uma forma especializada de etnografia voltada para estudos na Internet (HINE, 2005) e, também, um método interpretativo e investigativo para o comportamento cultural e de comunidades on-line (KOZINETS, 2014). Entendemos o blog como uma comunidade on-line, ou melhor, como uma "comunidade virtual", tal como definida por Howard Rheingold (1993, apud KONIZETS, 2014: 15-16). Para este autor, as "comunidades virtuais [são formadas] quando um número suficiente de pessoas empreende [...] discussões públicas por tempo suficiente, com suficiente sentimento humano, para formar redes de relacionamentos pessoais no ciberespaço". No caso em tela, estamos tratando de uma "comunidade virtual" que é organizada e mediada por Leonardo Boff e nosso objetivo é o de entender as categorias, as narrativas e os discursos mobilizados por ele, enquanto intelectual público, neste espaço de sociabilidade, qual seja, o blog, que ocupa o seguinte endereço www.leonardoboff.wordpress.com.

Para dar conta dessa tarefa, este texto está organizado em três partes: A primeira escrutina a trajetória de Leonardo Boff, como o objetivo de apresentar a origem social e histórica que estruturam a sua ação intelectual. A seguir, o texto aborda a trincheira pública a qual converteu-se Boff no século XXI. A reflexão segue a formação de Leonardo Boff como intelectual público e a sua opção pela Internet como o meio de exercitar a práxis intelectual. Por fim, o terceiro movimento é o de analisar os artigos de Leonardo Boff publicados no blog www.leonardoboff.wordpress.com entre 2011 e 2016. Tal intervalo é justificado em 2011 por ser a data de criação do blog; e 2016 pelo acontecimento do impeachment da presidenta da República Dilma Rousseff. 


\section{1) Leonardo Boff: um intelectual franciscano na cena pública}

A identidade pública de Leonardo Boff é de 1959. Foi neste ano que Boff ingressou na Ordem dos Frades Menores (franciscanos), sendo-lhe conferido o nome religioso de Leonardo - homenagem ao santo franciscano Leonardo de Porto Maurício (1676-1751). Seu nome de batismo é Genézio Darci Boff e nasceu na cidade de Concórdia, em Santa Catarina, aos 14 de dezembro de 1938. Neto de imigrantes italianos que se fixaram no campo brasileiro, desde a infância Boff teve contato com o catolicismo. Como realça Marcelo Timotheo da Costa “Ambiente esse que, unindo migração europeia, piedade católica já romanizada e pequena propriedade rural, irá fornecer à Igreja número significativo de vocações sacerdotais, fazendo que o Sul brasileiro fosse, até há pouco tempo, considerado uma espécie de "celeiro de vocações"” (COSTA, 2016:446). De seus onze irmãos, além dele, outros três optaram pela vida religiosa: Clodovis, Jenura e Lina (SILVA, 2012: 252). A opção de membros da família Boff pela vida religiosa, portanto, não surpreende.

Em 1964, Leonardo Boff foi ordenado sacerdote. Tendo cursado filosofia, em Curitiba, e teologia, em Petrópolis (RJ), e, em 1970, completou sua formação acadêmica com o doutoramento em Teologia e Filosofia, título obtido na Universidade de Munique. De volta da Alemanha, ainda em 1970, Leonardo Boff assumiu a cátedra de Teologia Sistemática no Instituto Teológico Franciscano, centro de formação de sua Ordem religiosa, situado em Petrópolis, na serra fluminense. Tornou-se ainda redator da revista internacional Concilium (em sua edição em língua portuguesa) e da Revista Eclesiástica Brasileira. Nesse mesmo ano, passou a compor o conselho da Vozes, uma das mais importantes editoras católicas, e subordinada aos franciscanos. É deste lugar social privilegiado que irá trabalhar na divulgação e ampliação da então nascente Teologia da Libertação (idealizada primeiro, poucos anos antes, pelo padre peruano Gustavo Gutiérrez), tendo sido o responsável pela Coleção "Teologia da Libertação".

Poucos meses após voltar ao Brasil, Leonardo Boff viaja para Manaus para pregar em um retiro destinado a padres e missionários que lá se encontravam. Boff narra a experiência como turning point. As condições de pobreza, desamparo, abandono e perigos que encontrou em Manaus teriam, em sua narrativa memorialística, produzido uma tal crise que provocou uma mudança de rumo em 
sua trajetória (BOFF, 1989). Marcelo Timotheo da Costa (2016: 447) chama atenção para o "choque sofrido pelo franciscano em virtude de seu contato com o que ele próprio, no futuro, chamaria de "Brasil profundo". O choque entre a teoria aprendida na Europa e nos seminários brasileiros e o cotidiano repleto de privações da vivência na região Amazônica, deixaram marcas em Leonardo Boff.

Tais marcas desaguaram em sua reflexão acerca de um novo caminho para o catolicismo, de uma nova eclesiologia: a Teologia da Libertação. A literatura sobre a Teologia da Libertação indica com clareza as relações estabelecidas entre a realidade de pobreza, subdesenvolvimento, injustiças e privação da América Latina e o pensamento progressista cristão latino-americano (LÖWY, 2000). E Leonardo Boff foi um dos expoentes dessa concepção. Seu livro, de 1972, Jesus Cristo Libertador-ensaio de Cristologia crítica para o nosso tempo inaugura as contribuições para/da Teologia da Libertação no Brasil.

De forma panorâmica, podemos acompanhar Michel Löwy (2000) que, ao investigar a Teologia da Libertação, relaciona as seguintes ideias-força dessa concepção: 1) a negação da separação entre histórias humana e divina, partição baseada no dualismo grego; 2) duras críticas ao sistema capitalista, tomado por iníquo e moralmente contrário ao espírito do cristianismo; 3) a crença na libertação histórica dos homens como prenúncio da libertação escatológica; 4) utilização do marxismo "como instrumento socioanalítico a fim de entender as causas da pobreza, as contradições do capitalismo e as formas de luta de classe. Tais ideias, ainda que tenham ensejado divergências entre os formulares da Teologia da Libertação, foram fundamentais na trajetória intelectual de Leonardo Boff.

Não cabe aqui explorar todos os argumentos da concepção, e sim realçar que é a partir das ideias-força da "libertação" e de "libertador", apresentadas tanto em ensaios como no livro citado, que Boff atuará na cena pública. Para ele "libertação" está imbricada na ideia de desenvolvimento. Há uma dura crítica às saídas reformistas para o problema do subdesenvolvimento. Boff defende uma posição na qual desenvolvimento e subdesenvolvimento são faces de uma mesma moeda. Em sua concepção há a produção de uma ordem em que o desenvolvimento dos países centrais só possível se forem mantidas as relações de dependência e subdesenvolvimento que esses países centrais estabelecem com os países da América Latina. Dessa forma, não que se falar em reformas, e sim ruptura. Dado este diagnóstico, Boff defenderá não só que os agentes da mudança são os oprimidos, ou seja, os pobres, os excluídos, os 
marginalizados, mas também que a libertação seja expressão de um projeto "assentado numa democracia radicalmente participativa, igualitária, respeitadora da diversidade e comunitária" (JESUS, 2009: 116). É neste sentido que emerge a ideia-força de libertação, que, conforme assinala Rodrigo Marcos de Jesus (2009: 112), “carrega, para além do dado científico da dependência da periferia, um conteúdo ético, político, denunciatório, utópico e religioso". Dessa forma, libertação é tanto práxis, que rompe com o status quo dependente, como a formação de uma nova consciência histórica.

Cumpre lembrar que a Igreja Católica entre 1959 e 1978 passou por um aggionarmento. Durante os papados de João XXIII (1959-1963) e Paulo VI (19631978) ocorreram importantes atualizações nas diretivas da Igreja Católica. A publicação das chamadas encíclicas sociais no papado de João XXIII e a convocação e realização de um novo concílio (o Vaticano II), o Conselho do Episcopado latino-americano (CELAM). Estas transformações - em especial, aquelas que foram promovidas a partir das decisões das II e III Conferências do CELAM, a primeira teve lugar em Medellin, Colômbia, em 1968; a outra ocorreu em Puebla, México, em 1979 - produziram novas formas de percepção sobre qual deveria ser a ação Igreja Católica no Século. Um exemplo desse câmbio e da força conquistada por membros do clero progressista nesses espaços institucionais pode ser apreendido com a divulgação das notas para a II Conferência Geral do Conselho Episcopal Latino-Americano (CELAM). Escrito pelo padre belga José Comblin, então professor de teologia no Seminário Regional de Recife, o texto discorrendo sobre o "papel da Igreja na história e política do continente, tratava de assuntos como a conquista e o exercício do poder e terminava por examinar a responsabilidade da Igreja no processo de desenvolvimento latino-americano, cuja injustiça com os pobres considerava gritante” (ALVES, 1993:). Uma mudança notável de perspectiva (ALVES, 1979).

As recepções e repercussões desse ideal libertador no seio da Igreja Católica foram inúmeras; desde a concepção de uma nova eclesiologia progressista às oposições mais ferrenhas à Teologia da Libertação. A mudança no Papado em 1978, com a eleição de João Paulo II, acelerou a reação à Teologia da Libertação. Cumpre destacar que as desconfianças da hierarquia católica com seus escritos já vinham ocorrendo desde o início dos anos de 1970. Boff, em vários momentos, teve que prestar explicações ao Vaticano sobre seus textos e ideias. Em 1984, Boff publica o livro Igreja: Carisma e Poder e as consequências renunciou às suas atividades de presbítero e se autopromoveu ao estado leigo. 
Cumpre algumas linhas sobre Igreja: Carisma e Poder. O livro é uma coletânea de ensaios que foram elaborados por Leonardo Boff ao longo dos anos 70 e início de 80 e publicados em diversas revistas teológicas nacionais e internacionais. Composta por treze artigos, apenas dois eram inéditos na ocasião da publicação, sendo que um deles parte da tese de doutorado do autor, defendida na Alemanha em 1970 e publicada em livro em 1972. A publicação resume muitas das propostas e novidades que emergiram no rico contexto dos anos de 1970 e 1980 na igreja brasileira e latinoamericana quando a teologia da libertação se alastra no continente e irradiam as Comunidades Eclesiais de Base (CEBs). Faustino Teixeira, em resenha publicada no Jornal do Brasil (14/05/2005) por ocasião da terceira edição da obra, enumerou com perfeição os seus pontos principais. Diz ele:

O livro de Leonardo Boff expressava uma demanda viva de novas forças eclesiais que brotavam das bases e suscitavam a sede de uma nova reestruturação da igreja católica, que pudesse favorecer uma maior participação dos pobres e dos leigos. Este foi o objetivo fundamental do livro: fornecer uma expressão teológica articulada da irrupção de um novo modo de ser igreja, que ficou conhecido internacionalmente como eclesiogênese, e que ganhava vida na experiência das comunidades eclesiais de base. Um traço marcante no livro Igreja: carisma e poder é a linguagem profética, que vem retomar um gênero que tem larga tradição teológica. Ela traduz um esforço vibrante, com toques de iracúndia sagrada, de recuperar um equilíbrio perdido entre instituição e carisma na igreja católica. Em todo o livro respirase um clima de retomada urgente da dimensão carismática e profética da igreja, e a busca de correção de dois desequilíbrios altamente problemáticos: o cristomonismo unilateral da tradição latina, marcada pela anemia do Espírito, e a hipertrofia do hierárquico institucional, que reforça o centralismo romano. Os diversos ensaios expressavam uma luta de anos encetada por Leonardo Boff em favor de uma organização mais participativa na igreja.

As críticas não demoraram, e a polêmica ganha novos contornos com a ação do cardeal Ratzinger, então prefeito da poderosa Congregação para a Doutrina da Fé (exSanto Ofício) e que, no futuro, viria ser escolhido papa, o Bento XVI (2005-2013). Em carta, endereçada em 1984, o cardeal Ratzinger expressou suas críticas às ideiais de Boff e em seguida convocou o franciscano Boff para um colóquio com ele no Vaticano 
que tratou dos problemas eclesiológicos em torno ao livro de Boff. No debate emergiu uma divergência essencial entre os dois sobre a interpretação dada pelo Concílio Vaticano II (1962-1965) à questão da verdadeira Igreja de Cristo. Não satisfeito com as explicações fornecidas pelo autor, o cardeal Ratzinger publica em 1985 uma notificação sobre o livro e submete o autor a um "silêncio obsequioso", depondo-o de todas as suas funções editoriais e de magistério no campo religioso. Dada a pressão mundial sobre o Vaticano, a pena foi suspensa em 1986, podendo retomar algumas de suas atividades na cadeira de Galilei Galileu. Mas, Boff continuará sob severa vigilância das autoridades e o cerco aperta por ocasião da Eco-92, no Rio de Janeiro, quando Boff vem novamente inquirido a recolher-se ao silêncio, devendo inclusive deixar de lecionar teologia e de dar entrevistas. Em 1992, sendo de novo ameaçado com uma segunda punição pelas autoridades de Roma, renunciou ao presbitério, declarando na ocasião que havia mudado "de trincheira para continuar a mesma luta" (www.leonardoboff.wordpress.com).

Efetivamente, Boff mudou de trincheira e, apesar de manter a mesma luta, também é bastante claro que alargou seus interesses após a renúncia. Os anos de 1990 veria surgir o intelectual ligado à política e ao meio-ambiente. Sua produção bibliográfica é bastante expressiva do câmbio. Tendo já escrito mais de 80 livros nas áreas de Teologia, Ecologia, Espiritualidade, Filosofia, Antropologia e Mística, dos quais muitos traduzidos para diversas línguas como o inglês, italiano, francês e alemão. Reconhecido internacionalmente por causa de sua luta em favor dos fracos, dos oprimidos e marginalizados e dos Direitos Humanos, foi agraciado com doutor honoris causa em Política pela universidade de Turim (Itália) e em Teologia pela universidade de Lund (Suécia), tendo ainda sido recebido vários prêmios no Brasil e no exterior.

Da Orbe católica, Boff dirigiu-se para o Urbi munido de vários signos de status próprios ao campo intelectual: professor de Ética, Filosofia da Religião e Ecologia na Universidade do Estado do Rio de Janeiro (UERJ), teólogo da libertação, escritor e conferencista nos mais diferentes auditórios do Brasil e do estrangeiro, assessor de movimentos sociais de cunho popular libertador, como o Movimento dos Sem Terra e as comunidades eclesiais de base (CEB's), entre outros. Muitas são as atividades públicas de Leonardo Boff, e em 2011 somou-se a elas a de blogueiro, que será explorada adiante.

Como já dito, a abertura para novos problemas e temas marcará a trajetória de Leonardo Boff após a sua renúncia. Câmbio que, defendemos aqui, expandiu a influência dele para além da fortaleza da Igreja Católica. Câmbio que rompe com essas 
muralhas e o consolida como um intelectual do mundo, um intelectual público. Norberto Bobbio assinala que caberia aos intelectuais atuar como um "elemento vivo e vivificador da "cidade"” (BOBBIO, 1997:22-23). A "cidade" entendida como a cena pública e os intelectuais tendo a função e responsabilidade de defender e alimentar valores morais deste mundo público. Leonardo Boff encarna de maneira singular tal missão.

Interessa-nos notar as "novas" preocupações para as quais se abre Boff a partir da década de 1990: da ética à política; da teologia à ecologia. Não que tenha abandonado a questões teológicas e/ou próprias ao mundo católico. Veremos que não o fez. Tendo sim agregado a elas "novos" problemas, mas sempre as analisou e interpretou sob o signo da ideia da libertação e sob a inspiração franciscana. O exemplo de São Francisco de Assis inspira Leonardo Boff. O santo protetor dos pobres e dos animais - e que a todos e a tudo, inclusive à morte, chamou de irmão ou de irmã -, para Boff, é quem inaugurou uma "Igreja na base". Mais do que isso, Francisco é, para nosso autor, o arquétipo do humanismo pregado por Boff: que vai além do mundo humano e que abarca toda a natureza e o próprio universo.

\section{2) Em uma nova trincheira: Leonardo Boff na "cidade"}

Boff é um intelectual público. E o que significa isso? É sabido que o surgimento dessa figura está relacionado à modernidade. Tocqueville, em $O$ antigo regime e a revolução mostra que foi a França que, em meados do século XVII, gerou uma nova figura, o intelectual público. Esse é quem que, só contando com o poder da pena e da ideia, ocupa a arena política, propõe a reforma do homem e da sociedade e é o protagonista da revolução mais radical e de consequências nunca vistas antes. Ainda, para Tocqueville, estes eram os hommes de letres que sem possuir "nem posições, nem honrarias, nem riquezas, nem responsabilidade, nem poder, tornaram-se de fato as principais personalidades políticas da época, e mesmo as únicas, uma vez que, enquanto as outras exerciam o governo, apenas elas tinham a autoridade?" (TOCQUEVILLE, 1989:144). Intelectual público, portanto, não é simplesmente o sujeito investido de funções públicas (sejam elas nos governos, nas magistraturas ou nos órgãos da Igreja), tampouco é o professor universitário convertido em funcionário público e pago pelo Estado. Para Tocqueville, o intelectual público é o sujeito engajado na política que ocupa 
o espaço público da "cidade". E Leonardo Boff, ao "mudar de trincheira", assume-se integralmente seu engajamento na vida da "cidade".

Tal engajamento assume formas diversas. Conforme a proposta de Norberto Bobbio em Os intelectuais e o poder: dúvidas e opções dos homens de cultura na sociedade contemporânea (1997), é possível definir o engajamento dos intelectuais de acordo com quatro tipos ideais, quais sejam: 1) com a presença do próprio intérprete no poder político; 2) intérpretes que influenciam o poder político, elaborando propostas ou fornecendo informações; 3 ) intérpretes que atuaram para legitimar o poder constituído; e 4) intérpretes críticos ao poder constituído.

Leonardo Boff irá se colocar na condição de um intelectual que se apresenta sempre como independente do poder constituído. Caso emblemático da relação que estabeleceu com o governo durante as presidências de Luiz Inácio Lula da Silva (20032011) e de Dilma Rousseff, ambos do Partido dos Trabalhadores (PT).

Outra forma de ler o engajamento de Boff é seguindo os termos de uma outra tipologia, também proposta por Norberto Bobbio, na qual os intelectuais são definidos ou como "ideólogos" ou como "expertos". Como nos adverte esse autor, o que os difere é a tarefa que desempenham no contexto político. Os "ideólogos" ou "intelectuais" são os sujeitos que, para Bobbio, fornecem os princípios-guia das sociedades, já os "expertos" ou "cientistas" seriam os que oferecem conhecimento-meio. Nos dois casos as ideias são forças sociais organizadoras do mundo social, tendo portadores sociais que são os seus executores. Leonardo Boff, neste caso, assume o papel do ideólogo. O ideólogo da Teologia da Libertação, dos pobres, dos oprimidos, de nova eclesiologia católica, das CEBs, de uma nova relação do Homem com a Gaia, o planeta. Essas são as muitas ideiasforça a guiar seu engajamento e, para dar conta delas, Boff utilizou muitas tribunas.

É impossível pensar o exercício de um intelectual público destituído de espaços que repercutam suas opiniões. Assim o desenvolvimento da imprensa e de uma esfera pública foram fundamentais para o surgimento desse tipo moderno de intelectual. $\mathrm{Na}$ verdade, são processos concomitantes, como indicou Habermas no pioneiro e clássico trabalho intitulado Mudança estrutural da esfera pública (HABERMAS, 1984). Como ele argumentou em seu trabalho, foi por intermédio da imprensa escrita que os intelectuais ganharam visibilidade e divulgaram suas opiniões, teses, argumentos e contra-argumentos. A advertência de John B. Thompson (1999), porém, sobre as dificuldades na explicação de Habermas para o diagnóstico da importância política do desenvolvimento da imprensa. As consequências normativas implícitas na concepção 
de público tal qual esboçado por Habermas na obra citada. Não cabe aqui aprofundar essa questão, e sim ressaltar os pontos da crítica de Thompson a Habermas. O primeiro deles é o de questionar o argumento habermasiano que considera que os consumidores são relativamente passivos e manipuláveis pela mídia, o que é considerado um exagero para Thompson. Um outro argumento de Habermas que é visto como problemático para Thompson, é a da "refeudalizada" - isto é, a esfera pública das sociedades modernas teria abandonado o debate crítico e passado a cultivar a aura pessoal o que a aproximaria das práticas teatrais das cortes feudais - da esfera pública nas sociedades modernas. Nesse ponto, Thompson nos auxilia ao advertir que

o desenvolvimento dos meios de comunicação criou novas formas de interação, novos tipos de visibilidade e novas redes de difusão de informação no mundo moderno ... [que nos impele a] repensar o significado do 'caráter público’ hoje, onde os indivíduos são capazes de interagir com outros e observar pessoas e eventos sem sequer os encontrar no mesmo ambiente espaço-temporal (1999:72).

Manuel Castells $(1996 ;$ 2017) chamou essa nova configuração social de sociedade em rede. Caracterizada por formas de poder multidimensional e que se organiza em torno de redes que o exercem "sobretudo influenciando a mente humana (mas não apenas)" por meio das mass media, que são, em última análise, fontes “decisivas de construção de poder” (CASTELLS, 2017: 22). Mas, as redes midiáticas não pairam tampouco se descolam das redes dos vários outros domínios da atividade humana. Dessa forma, as redes competem e cooperam entre si, formando novas redes ad hoc em torno de projetos comuns. Castells (2017: 23) argumenta que todas têm o mesmo interesse: "controlar a capacidade de definir as regras e normas da sociedade mediante um sistema político que responde basicamente a seus interesses e valores”. E quem o poder é exercido nessa sociedade em rede? A resposta de Castells é de que o poder é exercido (re)programando-se redes. Isto abre para tentativas deliberadas de alteração do poder, ou seja, para o estabelecimento de redes de contrapoder que buscarão reprogramar as redes em torno de outros interesses e valores. Para refletirmos com Pierre Lévy, os novos espaços de comunicação que se abriram com a Internet expressam 
o surgimento de um novo universal, diferente das formas culturais que vieram antes dele no sentido de que ele se constrói sobre a indeterminação de um sentido global qualquer [...]. A nova universalidade não depende mais da autosuficiência dos textos, de uma fixação e de uma independência das significações. Ela se constrói e se estende por meio da interconexão das mensagens entre si, por meio de sua vinculação permanente com as comunidades virtuais em criação, que lhe dão sentidos variados em uma renovação permanente (1999: 12 e 14).

Refletindo sobre o blog de Leonardo Boff é bastante sugestivo pensá-lo em concordância com esses últimos entendimentos de que as novas formas de comunicação fomentam uma nova cultura. Suas publicações são tentativas de reelaborar interesses e valores, buscando que a vitória na luta simbólica esteja na origem de novos guias para a ação humana. Seu blog é, portanto, um mecanismo de construção de contrapoder, de mudança social.

Não há dúvida de que o desenvolvimento da Internet e das formas contemporâneas de informação, permite formas horizontalizadas de informação e de produção de informação, além de uma relação mediada em que a prática da comunicação é outra. Se, para parte da literatura, o meio era a mensagem com o desenvolvimento das novas Tecnologias de Informações (TICs) a mensagem assume proeminência em relação ao meio. Conforme Pierre Lévy, as tecnologias digitais de informações constituem seu próprio espaço: o ciberespaço, ou "rede" comportando a infraestrutura material da comunicação digital e o universo oceânico de informações que ela abriga, assim como os seres humanos. E cria também a "cibercultura", que foi definida por Lévy como "o conjunto de técnicas (materiais e intelectuais), de práticas, de atitudes, de modos de pensamento e de valores que se desenvolvem juntamente com o crescimento do ciberespaço" (LÉVY, 1999: 17).

Os blogs são espaços virtuais caracterizado pela publicação de entradas chamadas de postagens, ou post - organizadas em ordem cronológica inversa, com a mais recente tendo destaque. Tais espaços mediados por um computador favorecem a comunicação e a participação. O primeiro blog foi criado em 1997 por John Barger. Dois anos depois o lançamento do primeiro software gratuito para criação de blogs permitiu que os blogs se tornassem bastante populares. Os blogs são canais de comunicação acessíveis, pouco custosos e flexíveis. Tais características explicam a 
atração que exerce para múltiplos públicos que o usam como meio de comunicação (AMARAL et alli, 2009). Seguindo Bolaños e Brittos (2010: 242), podemos afirmar que os blogs têm servido especialmente ao "ator social interessado em criar um capital simbólico e, assim, melhor valorizar-se no mercado cultural, desta forma podendo participar de um lugar de comunicação bastante horizontalizado e que se amplia dia a dia".

Conforme assevera Lèvy (1999: 53) “[...] as pessoas que frequentam várias comunidades virtuais fazem passar, de uma para outra, as informações que consideram pertinentes". Dessa maneira é possível pensar que, a produção de mensagens nos meios de comunicação na sociedade de redes passa, assim, por processos que tem indicado que os novos espaços de debate na Internet (blogs, microblog, redes sociais, entre outros) atuam para juntar os iguais, e não para fazer "conversar" os diferentes. Ainda que, devase frisar, essa "conversa" expresse possibilidades de transformação do mundo social a partir da organização dos indivíduos/ blogueiros em redes, expressando antagonismos

O blog, portanto, constitui-se em um espaço de sociabilidade, tal qual os salões literários do século XVIII (SIRINELLI, 1996), assumindo uma função de caixa de ressonância para o Boff, o intelectual cristão. A hipótese aqui desenvolvida é a de que Leonardo Boff se utiliza a Rede Mundial de Computadores para constituir "redes" de iguais. Buscarei mostrar que, apesar do blog manter aberto um espaço para comentários, não há uma proposta de diálogo com os "desiguais" figurando apenas para que os leitores reajam ao que foi publicado. Por fim, a atuação de Boff nos permite revisitar o conceito clássico de intelectual e, inclusive, refletir sobre o intelectual como o ator que tem na força moral, não-política, a sua fonte de legitimidade e legitimação.

A seguir mostraremos como Boff encontrou na internet - um media líquido por excelência - um espaço para exercer o papel de ideólogo da perspectiva progressista, na qual foi mantida a proeminência da defesa da ideia-força de "libertação" como práxis e horizonte de expectativa para uma sociedade fundada em maior justiça social.

\section{3) www.leonardoboff.wordpress.com: opção pelos pobres, revolução e ação política}

Como já dito, Leonardo Boff começou a escrever em seu blog em 2011, mais precisamente, em 14 de fevereiro. Antenado com as novas tecnologias digitais de informações, Boff já tinha conta no Twitter, portanto, o blog não foi sua primeira incursão 
nesses espaços de sociabilidade digitais. De início apresentou aos seus seguidores seis postagens, que versavam sobre ecologia e o Antropoceno. Sua primeira postagem é sugestiva da potência da ideia-força da libertação enquanto paradigma para transformação social. Com o título Uma revolução ainda por fazer, Boff defende que apenas uma crise nas mentalidades tal qual a ocorrida nos séculos XVI pode via a fundar o paradigma próprio a nova era: o ecozóico. Boff já em sua primeira postagem deixou claro de que lugar, para quem e qual o seu papel naquele contexto. Há, para ele, uma revolução a fazer, como diz o seu título, isto porque apenas uma revolução pode parar a degradação da Terra. Tal revolução seria a base teórica de uma nova cosmologia, fundada na ideia-força da interdependência e mutualidade entre todos os seres vivos e que deve ser plasmada na consciência ${ }^{1}$.

Entre o início do blog e junho de 2016, houve constante atualização e discussão no espaço virtual. Além disso, ainda em 2011, no mês de outubro, seus artigos passaram a ser postados em inglês e espanhol, e no ano seguinte somou-se a eles versões em italiano e alemão. As postagens do tema Política, sejam escritas por Boff ou por convidados dele, foram regulares nesses anos como podemos ver na tabela abaixo:

\section{Tabela 1}

Postagens do tema Política.

\begin{tabular}{|l|l|}
\hline Ano & Número postagens do tema política \\
\hline 2011 & 43 (início em fevereiro) \\
\hline 2012 & 82 \\
\hline 2013 & 83 \\
\hline 2014 & 80 \\
\hline 2015 & 89 \\
\hline 2016 & 86 (até outubro) \\
\hline Total & 463 \\
\hline
\end{tabular}

Fonte: www.leonardoboff.wordpress.com

Ainda refletindo sobre os aspectos mais formais, é preciso atentar para o predomínio e a mudança dos problemas abordados por Leonardo Boff entre 2011 e 2016.

\footnotetext{
1 Disponível em <https://leonardoboff.wordpress.com/2011/02/14/uma-revolucao-ainda-por-fazer/>.
} Acesso em: 05 dez2018. 
A conjuntura organiza sua produção, embora a presença de post atemporais não tenha desaparecido. Estes versam sobre religiosidade, ecologia e crise do capitalismo. Também é preciso ressaltar que seus primeiros textos receberam poucos comentários, como era de se esperar ainda que seja preciso destacar que Boff fez com sucesso propaganda do blog entre seus seguidores no Twitter. Ainda não surpreende constatar que, inicialmente, a maior parte desses comentários foi elogiando a iniciativa. A repercussão entre os "iguais" somado a escolha dos temas que foram inicialmente tratados também podem ter contribuído para tal desenlace.

De maneira geral, entre 2011 e 2016, prevalecem postagens que abordaram questões sobre ecologia, religião, política internacional, política brasileira e temas ligados à ciência, à ética, tais como: o ataque aos EUA em 11 de setembro de 2011, o atentado ao Charlie Hebbo, o golpe ocorrido no Brasil em 2016, o Partido dos Trabalhadores (PT) e a Teologia da Libertação. Essas também foram as que receberam altos números de comentários tanto de pessoas que compartilhavam os posicionamentos de Boff como de quem divergia (estes em números superiores). Destaque-se que as relações foram se estabelecendo entre Boff e o público a partir dos comentários às suas postagens. No primeiro mês do blog, as postagens receberam no máximo doze comentários; em abril, o cenário já mudou. A publicação Oração de Nietzche: Ao Deus desconhecido recebeu 104 comentários.

Em 09 de agosto de 2011, Boff publicou postagem sobre os quarenta anos da Teologia da Libertação, que teve 170 comentários. Seu texto reitera enfaticamente a ideia-força da libertação como guia de sua ação no mundo e faz uma defesa intransigente da Teologia da Libertação. Diz ele ${ }^{2}$ :

A Teologia da Libertação participa da profecia de Simeão a respeito do menino (Jesus): ela será motivo de queda e de elevação, será um sinal de contradição (Lc 2,34). Efetivamente a Teologia da Libertação é uma teologia incompreendida, difamada, perseguida e condenada pelos poderes deste mundo. E com razão. Os poderes da economia e do mercado a condenam porque cometeu um crime para eles intolerável: optou por aqueles que estão fora do mercado e são zeros econômicos. Os poderes eclesiásticos a condenaram por cair numa "heresia" prática ao afirmar que o pobre pode ser

${ }^{2}$ Disponível em https://leonardoboff.wordpress.com/2011/08/09/quarenta-anos-da-teologia-da-libertacao/ acesso em $05 \operatorname{dez} 2018$. 
construtor de uma nova sociedade e também de outro modelo de Igreja. Antes de ser pobre, ele é um oprimido ao qual a Igreja deveria sempre se associar em seu processo de libertação. Isso não é politizar a fé, mas praticar uma evangelização que inclui também o político. Consequentemente, quem toma partido pelo pobre-oprimido sofre acusações e marginalizações por parte dos poderosos seja civis, seja religiosos. ${ }^{3}$

Ainda na mesma postagem, Boff reitera como o fim da relação hierarquia estreita com a Igreja Católica, com a sua abnegação do sacerdócio não foi, de modo algum, sinônimo de renúncia da posição teológica que havia adotada. Na condição de leigo, Boff permaneceu fiel aos postulados da Teologia da Libertação. A citação abaixo, apesar de longa, é importante, pois apresenta tanto a continuidade da libertação na conformação da trajetória de Boff, quanto a crítica à Igreja, ou melhor dizendo, aos mandos e aos desmandos da hierarquia católica e a opção desta mesma Igreja Católica por um modelo, julgado por Boff, como ultrapassado. Diz ele:

Por outro lado, a Teologia da Libertação representa uma benção e uma boa nova para os pobres. Sentem que não estão sós, encontraram aliados que assumiram sua causa e suas lutas. Lamentam que o Vaticano e boa parte dos bispos e padres construam no canteiro de seus opressores e se esquecem que Jesus foi um operário e pobre e que morreu em consequência de suas opções libertárias a partir de sua relação para com o Deus da vida que sempre escuta o grito dos oprimidos ${ }^{4}$.

As repercussões ao post sobre os quarenta anos da Teologia da Libertação nos dão pistas sobre a comunidade virtual constituída com o blog. Há mais comentários contrários à Teologia da Libertação. Apesar disso, análise mais detida dos conteúdos e dos nicknames nos mostram que a pertença católica é traço comum entre a unir os comentadores. Muitos deles, independentemente da posição em relação à postagem, reforçam o próprio lugar de fala enquanto membros da Igreja Católica. Podemos afirmar que a maioria dos integrantes de tal comunidade compartilhe esse perfil, uma vez que Boff construiu sua reputação intelectual e conquistou visibilidade nas hostes católicas.

\footnotetext{
${ }^{3}$ Disponível em: <https://leonardoboff.wordpress.com/2011/08/09/quarenta-anos-da-teologia-dalibertacao/. Acesso em: $05 \mathrm{dez} 2018$.

4 Disponível em: <https://leonardoboff.wordpress.com/2011/08/09/quarenta-anos-da-teologia-dalibertacao/. Acesso em: $05 \mathrm{dez} 2018$.
} 
Isso é posto claramente na resposta dada por ele a uma comentadora, que o parabeniza pelo blog e chama atenção para as aberturas que se abrem com a Internet. Escreveu Boff: “[...] Todos os que nos metemos com questão de justiça social, a partir das vítimas e daí a libertação, formamos uma como que comunidade de destino. Mesmo longe estamos perto nos sonhos e na mesma caminhada. Caminhemos juntos, irmã, que o Crucificado e Ressuscitado vem conosco".

A ideia-força de "Comunidade de destino" assume lugar importante na economia discursiva de Boff. Tal fenômeno se estabelece em contraposição à comunidade de origem. Enquanto nesta as relações são formadas a partir de laços de sangue; na comunidade de destino se refere à reunião de grupo de pessoas que estabelecem vínculo de amizade e confiança e imaginam seu próprio destino. O espírito comunitário é oriundo ou de elementos físicos/culturais ou de elementos subjetivos comuns, cujas vivências e a experiências coletivas forjam traços identitários (Bosi, 1995). É interessante assinalar que os escritos de Boff em seu blog a todo momento reiteram a força da perspectiva franciscana da vivência/experiência com os pobres, os marginalizados, os despossuídos, ou seja, as vítimas e como é ela quem fornece as bases do pertencimento a essa comunidade de destino. Em Boff, o compartilhamento não é produto de interações relativas ao meio físico, e sim subjetivo/psicológico, que aproxima e que ata os indivíduos em uma rede de solidariedade e pertencimento.

Tal ideia - "comunidade de destino - não lhe é própria. Michel Maffesoli (2006: 279) chama atenção para o fato de que a participação nas comunidades de destino "gera uma comunhão quase mística", que ultrapassa a singularidade individual e se perde (e acha) numa globalidade. Ressalte-se, ainda seguindo Maffesoli (2006), que o mesmo fenômeno da comunidade de destino nos permite compreender a rejeição, o estigma, a marginalização daqueles que não são reconhecidos com partícipes da comunidade. Tal reconhecimento parte tanto do grupo que forma a comunidade de destino como por aqueles que optam por tê-lo.

No blog, Boff e o público-leitor formam uma comunidade de destino que produz determinadas marginalizações simbólicas. De forma geral, a divergência não leva à nem exclusão nem a rejeição, conforme preconizado em Maffesoli (2006), e sim a um reconhecimento negativo. Caso exemplar foi a postagem sobre a morte de Bin Laden em que defendeu que a ação do governo americano fora contrária à justiça e movida por vingança, uma vez que ferira as leis internacionais. Tal post recebeu 62 
comentários. A maioria esmagadora apoiou o posicionamento de Boff. Um deles, porém, que usou o sugestivo pseudônimo de Luiz Bento Ratzinger, questionou seus argumentos e reforçou em chave negativa a identidade do autor da postagem com a Teologia da Libertação e com o pensamento católico progressista. De forma que, a presença dos desiguais no blog não significa necessariamente um diálogo, e sim que reiteradamente se fixe determinada opinião/posição política. Outro leitor/participante de seu blog, inquiriu Boff acerca de uma opinião que ele deu por ocasião do 11 de setembro na qual sugere que se ponha sob perspectiva o ataque ao Pentágono. A resposta de Boff a esse leitor, ao mesmo tempo que estabeleceu um diálogo, mostrou a dificuldade em tratar com "desiguais", ou seja, com aqueles que defendem posições políticas e teológicas diferentes daquelas compartilhadas pela comunidade de destino. Escreveu Boff:

[...] É bom ver os dois lados para não cair na ingenuidade de que o terrorismo está só de um lado. Hoje os USA se transformaram num Estado terrorista onde o presidente publicamente se propõe um assassinato: 'nós vamos matar bin Laden'. Desde quando um Executivo tem o direito de mandar matar, quando é tarefa da justiça prender, julgar e se for o caso condenar à morte. [...] Existe ética, meu irmão e leis internacionais que nos fazem civilizados e não nos deixam voltar ao estado das cavernas, coisa que acho você também não quer. ${ }^{5}$

A réplica também explicita a filiação de Boff aos direitos humanos enquanto marco que ele considera que distingue civilização de barbárie. Há nesse aspecto uma observação que assinala a complexidade do pensamento político de Boff. Cumpre lembrar que a defesa de limites ao poder do Estado, portanto, do Estado de Direito é uma bandeira do jusnaturalismo. Norberto Bobbio afirma que "no Estado de direito, o indivíduo tem, em face do Estado, não só direitos privados, mas também direitos públicos. O Estado de direito é o Estado dos cidadãos" (BOBBIO, 2004:58). A questão é que a delimitação da cidadania traz tendências à especificação, e estas afetam a efetivação da proteção internacional dos indivíduos (BOBBIO, 2004). Tais problemas são ressaltados por Boff em sua crítica à intenção/ação norte-americana e configuram

\footnotetext{
${ }^{5}$ Disponível em https://leonardoboff.wordpress.com/2011/09/13/o-que-motivou-o-11-de-setembro/ acesso em $05 \operatorname{dez} 2018$
} 
marco de pertencimento ou de exclusão à comunidade de destino que é repercutida por ele no blog.

A opção pelos pobres (lema da Teologia da Libertação) é tão central no pensamento político de Leonardo Boff que os governos de Luiz Inácio Lula da Silva (2003-2011) e Dilma Rousseff (2011-2016) foram lidos por ele nessa chave explicativa. Há inúmeros post que ilustram tal interpretação. Vamos trabalhar aqui com dois exemplos que consideramos emblemáticos, uma vez que sintetizam seus conceitos centrais.

O primeiro deles é a postagem de 20 de setembro de 2014, na qual Boff declarou seu voto para presidente da República em Dilma Rousseff, do PT, obteve 192 comentários, intitulada As muitas razões para votar em Dilma. Nela, Boff enumerar as razões de sua opção na candidatura petista, para além do "esboço de projeto político", que, em sua opinião, é ainda o mais adequado ao Brasil. A primeira delas é a "revolução democrática e pacífica" que para ele ocorreu no país em 2002 com a eleição do Lula. Revolução porque foi uma alternância da classe social que conduzia o Estado brasileiro; revolução porque as classes subalternas do país elegeram um dos seus, que implementou políticas aspiradas por milhões de excluídos; revolução porque, em sentido dado ao conceito por Caio Prado e citado por Boff, levou o país a trilhar um novo rumo. A eleição de Lula inaugura a revolução; a Dilma consolidaria a revolução. A segunda razão é o que Boff chama de revolução "rumorosa" e revolução "silenciosa": a primeira, resultado das políticas sociais de enfrentamento e redução da pobreza; a outra, a política educacional que criou várias universidades federais, cursos profissionalizantes, etc. Outra razão era as baixas taxas de desemprego; e a quarta, e última, razão era que apesar de reconhecer que "em alguns estratos do PT houve corrupção", Dilma não tinha sobre ela nenhuma acusação de corrupção. A declaração de voto na candidatura petista não significou, porém, alinhamento absoluto. Boff também deixou claro que estava disputando as pautas daquele projeto. Não por acaso relaciona os caminhos a avançar: um governo centrado em democracia participativa; redução da desigualdade social; sustentabilidade ambiental; reforma agrária; proteção das terras indígenas. Novamente, os excluídos ocupam o centro do argumento de Boff.

O outro exemplo é a postagem por ocasião da aprovação do pedido de impeachment da presidenta Dilma. Nomeado por Boff de golpe parlamentar, tal acontecimento é entendido como "anti-revolução". Na postagem de 30 de abril de 2016, Boff reitera a chave interpretativa de que a condução do Estado brasileiro pelos presidentes petistas foi 
uma revolução, pois foram os "sem poder: os vindos da senzala, das periferias e dos fundões de nosso país, do novo sindicalismo, dos intelectuais de esquerda, da Igreja da libertação com suas milhares de comunidades de base" que conseguiram "transformar o poder social que haviam acumulado num poder político-partidário". Tais atores, "via PT operaram analiticamente uma autêntica revolução", que, para Boff, levou à reação e ao pedido de impeachment de Dilma Rousseff. Este, em seu entendimento, consistia na "negação da revolução", em um processo de retorno à ordem anterior: à "democracia patrimonialista". O sentido dado por Boff ao acontecimento do impeachment como "antirevolução" tem traços singulares uma vez que posiciona no centro da disputa a presença ou não das classes subalternas no poder político. Dessa forma, o que estava em questão era a opção pelos pobres, que voltava a ser deslocada para longe das decisões públicas. Evidentemente, tal posicionamento produziu oposições fortes, que nos apresentam claramente o apelo da comunidade de destino como fenômeno de exclusão. Em resposta a um comentador Leonardo Boff termina por responder assim: "vc não tem nenhuma obrigação em me seguir, e eu não tenho nenhuma obrigação em lhe responder. Desculpe."

A relação com os comentaristas reitera o ideal comunitário que organiza o blog. Há, ali, várias "comunidades de destino" que disputam interpretações sobre o Brasil e o mundo. Salta aos olhos o uso de nickname, que garante anonimato. Ressalta-se também o apelo aos mesmos argumentos e fontes de informação por parte dos partícipes do blog. Mais uma vez podemos afirmar que o diálogo é mais aparente do que real. São pontos de vista conflitantes e pouco abertos ao outro, o que parece confirmar o blog como uma sociedade de "iguais". Isso também se explicita nas participações de Boff no espaço dos comentários.

É interessante notar que ele escolhe com cuidado seus interlocutores. A seleção é menos o sujeito da ação e muito mais o argumento esgrimido pelo comentarista de seu artigo. Isso fica claro na resposta ao comentário de uma leitora recebida na postagem "As muitas razões para votar em Dilma”, que, como vimos acima, Boff enumera os pontos positivos dos governos petistas e os primeiros comentários feitos são críticos. Boff não intervém, não responde. Um dos comentaristas contrários ao seu post utiliza a mesma estrutura formal da do comentário Boff e enumera razões para não se votar na Dilma. Boff novamente não responde. É uma comentadora que vem em defesa da postagem de Boff. Para isso faz uso de um argumento de autoridade. Boff então entra na conversa e a redireciona, buscando dialogar com seu oponente no campo dele. Para isso ele também faz uso de um argumento de autoridade, só que no caso de um autor capitalista - George Soros. Tal 
"deixa" permite aos seus leitores continuarem a contenda sem a interferência de Boff, que volta a comentar quando é postada uma mensagem acusatória às igrejas cristãs (a Católica, também as evangélicas). A intervenção de Boff nesse e em outros casos parecido será sempre a da moderação. O que, dado a amplitude de temas tratados nas postagens de Boff (ética, religião, política, etc), é a atuação mais frequente dele nos comentários.

Tais exemplos da atuação de Boff indicam que há um paradoxo aqui: o blog é um espaço de (re)afirmação da identidade dessa comunidade que compartilha os valores da opção pelos pobres, da "revolução" que para Boff ocorreu no Brasil dos anos de 20032016 e pela democracia. É para marcar posição. Ao mesmo tempo, é um espaço de exercício do intelectual público Leonardo Boff, portanto, a controvérsia, a disputa de posições, a disposição e disponibilidade para o diálogo estão presentes.

\section{Considerações finais}

As postagens de Leonardo Boff que tiveram maior audiência pública (uso o termo aqui como sinônimo de comentários, ou seja, de troca entre Boff e seus leitores e entre os próprios leitores) entre 2011 e 2016 tinham características parecidas, isto é, as questões eram claramente de tomada de posição. Nesses casos, a comunidade de destino ou, em outros termos, a sociedade dos "iguais" teve que interagir com quem divergia de Boff. E o diálogo estabelecido é revelador, por um lado, das dificuldades da construção de consensos na esfera pública e, num sentido mais preciso, de como as redes sociais e suas possibilidades democráticas podem também ser espaços de não-dialógicos. Por outro lado, essas mesmas postagens podem ser lidas também enquanto espaços/acontecimentos que permitiram que sujeitos com visões e perspectivas comuns construíssem laços e experimentassem o espaço discursivo do blog como a base subjetiva que leva a encontros e a constituição da tal comunidade de destino, imaginada por Leonardo Boff.

Norberto Bobbio ao discutir a responsabilidade dos intelectuais chama atenção para o ajuste de contas que o intelectual, em função do peso e da influência (poder) que exercem, enfrentam; para a responsabilidade de suas escolhas e consequências frente ao homem- massa que "perde a própria personalidade e se "perde e se anula no grupo, não fala, mas grita; não discorre, mas injuria; não raciocina mas exprime o próprio pensamento no estilo primitivo do slogan; não age mas se agita ...” (Bobbio,1997:100). 
Leonardo Boff, em seu blog, tem conhecimento de quais são as suas escolhas e dos porquês de cada uma delas; sabe ainda das suas consequências e as enfrenta no espaço dos comentários. Boff cumpre, assim, o papel de intelectual tanto com sua atividade quanto com a responsabilidade com que executa tal função.

Lado a lado ao papel ativo de ideólogo - aqui entendida no diapasão apresentado por Norberto Bobbio, qual seja: como um tipo ideal que reúne aqueles que fornecem "princípios-guia aos detentores do poder político atual ou potencial" (Bobbio, 1997:97) - que Leonardo Boff exerce em suas postagens, há também o exercício do experto (também em alusão à definição de Norberto Bobbio que os define como aqueles que fornecem conhecimento técnico e que portanto são regidos por uma ética da responsabilidade) quando desempenha o papel de moderador no espaço dos comentários, ou quando municia o debate com dados técnicos, tais como a referência bibliográfica do George Soros que citei acima.

O duplo papel enunciado acima revela um movimento que procura controlar parcialmente, é claro, a recepção de seus escritos e de seus posicionamentos. Dito de outra forma, Leonardo Boff, no blog, se utiliza dos comentários menos para afirmar pontos de vista apresentados no artigo que provoca um debate do que para firmar seu engajamento por uma ordem social e política que supere o capitalismo, por uma Igreja voltada para os pobres, e por uma orientação política nacional que combata as enormes desigualdades do país que excluí a maioria da população. Nesse sentido, Boff tem clareza da responsabilidade de seus escritos, de suas palavras e, é importante ressaltar, há um evidente esforço em não as usar para produzir violência. De um lado, isso produz uma responsabilização pelos efeitos das suas próprias palavras. Do outro, reitera a fala para os "iguais", para a comunidade de destino a que se filia.

\section{Fonte}

BOFF, Leonardo. leonardoBOFF.com [Internet]. Rio de Janeiro: Leonardo Boff.

Disponível em: 〈https://leonardoboff.wordpress.com/〉. Acesso em: 30 mar. 2018. 


\section{Referências Bibliográficas}

ALVES, Márcio Moreira. (1979). A Igreja e a política no Brasil. São Paulo: Brasiliense. (1993). 68 mudou o mundo. Rio de Janeiro: Nova Fronteira.

AMARAL, Adriana; RECUERO, Raquel; MONTARDO, Sandra (2009). Blogs: mapeando um objeto. In: Blogs.Com: estudos sobre blogs e comunicação./ Adriana Amaral, Raquel Recuero, Sandra Montardo (orgs.)- São Paulo: Momento Editorial. BOBBIO, Norberto (1997). Os intelectuais e o poder: dúvidas e opções dos homens de cultura na sociedade contemporânea. Tradução de Marco Aurélio Nogueira. São Paulo: Editora da Universidade Estadual Paulista. (2004). A era dos direitos / tradução Carlos Nelson Coutinho; apresentação de Celso Lafer. - Nova ed. - Rio de Janeiro: Elsevier.

BOFF, Leonardo (1989). Um balanço de corpo e alma. In: BOFF, Leonardo et al. $O$ que ficou... balanço aos 50. Petrópolis: Vozes.

BOLAÑO, César Ricardo Siqueira; BRITTOS, Valério Cruz (2010). Blogosfera, espaço público e campo jornalístico: o caso das eleições presidenciais brasileiras de 2006. Revista Intercom - Revista Brasileira de Ciências da Comunicação. São Paulo, v. 33, n. 1, p.237-256, jan./jun.

BOSI, Eclea (1995). Memória e sociedade: lembranças de velhos. 4. ed. São Paulo, Companhia das Letras.

CASTELLS, Manuel (1996). A sociedade em rede. São Paulo: Paz e Terra. . (2017). Redes de indignação e esperança: movimentos sociais na era da internet. Rio de Janeiro: Zahar.

COSTA, Marcelo Timotheo da (2016). Em nome do Pai: o Francisco de Assis de Leonardo Boff. Topoi, Rio de Janeiro, v. 17, n. 33, p. 444-467, jul./dez.|

HABERMAS, Jünger (1984). Mudança estrutural da esfera pública: investigações quanto a uma categoria da sociedade burguesa. Rio de Janeiro: Tempo Brasileiro.

HINE, Christine (Org.) (2005). Virtual Methods. Issues in Social Research on the Internet. Oxford: Berg.

JESUS, Rodrigo Marcos de (2009). Religião como fé e política: o cristianismo libertador em Leonardo Boff. Faculdade Jesuíta de Filosofia e Teologia (Dissertação de mestrado). Belo Horizonte.

KOZINETS, Robert. V (2014). Netnografia: Realizando pesquisa etnográfica online. Porto Alegre: Penso.

LÉVY, Pierre (1999). Cibercultura. São Paulo: Ed.34.

LÖWY, Michael (2000). A guerra dos deuses: religião e política na América Latina. Petrópolis: Vozes.

MAFFESOLI, Michel (2006). Comunidade de destino. Horizontes Antropológicos, Porto Alegre, ano 12, n. 25, p. 273-283, jan./jun.

MANNHEIM, Karl (1986). Ideologia e Utopia. Tradução de Sérgio Magalhães Santeiro; Revisão Técnica de César Guimarães. Rio de Janeiro: Ed. Guanabara.

SILVA, Bruno Marques (2012). Cristão, franciscano e teólogo. Uma análise da trajetória de Leonardo Boff. In: Intelectuais e militância católica no Brasil/ RODRIGUES, Cândido Moreira \& PAULA, Christiane Jalles de (Orgs). Cuiabá: EdUFMT. pp. 241-277.

SIRINELLI, Jean-François (1996). Intelectuais. In. Por uma história política. Rio de Janeiro René Remond (Org.) Editora UFRJ.

TEIXEIRA, Faustino (2005). Resenha. Jornal do Brasil (14/05/2005). 
THOMPSON, John B (1998). A mídia e a modernidade: uma teoria social da mídia. Petrópolis (RJ): Vozes.

TOCQUEVILLE, Alexis de (1989). O antigo regime e a revolução. Brasília: Editora Universidade de Brasília; São Paulo: Hucitec.

WINOCK, Michel (2000). O século dos intelectuais. Tradução de Eloá Jacobina. Rio de Janeiro: Bertrand Brasil.

Artigo recebido em 25 de novembro de 2018.

Aprovado em 07 de dezembro de 2018.

DOI:10.12957/intellectus.2018.39089 